\title{
The Impact of Share Repurchase on R\&D Expenditure: An Empirical Study from High-tech industry
}

\author{
Hongwei Cheng ${ }^{1}$; Liang Yin ${ }^{1, a^{*}} ;$ Xinwei Luo $^{1}$ \\ ${ }^{1}$ Business School, Sichuan University, Chengdu, China
}

\begin{abstract}
After the policy was released in 2018, listed companies increased the frequency and amount of repurchases. Some studies believe that managers will give up long-term investment which is beneficial to the sustainable development of enterprises due to the short-term performance response caused by share repurchases. This paper took the repurchase firms in the high-tech industry from 2008 to 2018 as samples, it is found that the company's share repurchase promotes $R \& D$ expenditure and will not reduce expenditure in R\&D for short-term stock price reaction. Furthermore, the heterogeneity study found that in state-owned firms, the company's share buybacks have a more significant role in promoting R\&D expenditure.
\end{abstract}

\section{Introduction}

After the CSRC issued the opinions on supporting the repurchase of shares by listed companies in 2018, listed companies frequently repurchase shares. In 2019, a total of 1323 repurchase announcements were issued, involving 60 billion yuan. As share repurchase will cause the stock price to rise in a short term, it is conducive to the short-term performance of firms. Some scholars have pointed out that the sake of such short-term interests, company managers will abandon valuable investments or reduce R\&D expenditure that is conducive to the long-term development of firms (Shane, 2019) ${ }^{[5]}$. Compared with other industries, for the high-tech industry, investment in R\&D is a solid foundation for long-term development of the company and an important source of corporate competitive advantage. Will the high-tech industry reduce corporate R\&D expenditure for this short-term benefit?

Based on the data of 7163 repurchases from 2008 to 2018 , this paper uses logit regression model to study whether companies will reduce their investment in R\&D due to repurchases in high-tech industries. Different from the research findings of Shane (2019) ${ }^{[5]}$, this paper finds that in the high-tech industry, companies will not reduce their investment in $\mathrm{R} \& \mathrm{D}$ due to share repurchases.

The main contribution of this paper is to supplement the existing literature. Current research finds that listed companies use repurchases in exchange for $R \& D$ expenditure, but this paper finds that listed companies in the high-tech industry do not have short-term performance in exchange for long-term corporate development. On the contrary, the share repurchase of listed companies is positively correlated with $R \& D$ expenditure. The findings of this paper supplement the literature on repurchase and $R \& D$ expenditure.

\section{Literature review and research hypotheses}

Share repurchase has become a common way of capital operation in developed countries. There are abundant researches on the impact of share repurchase (Almeida, 2016; Dittmar,2015; Hillert,2016; Shane,2019; Tong,2016) ${ }^{[1,3-6]}$. Regarding the relationship between share repurchase and R\&D expenditure, Almeida (2016) ${ }^{[1]}$ and Dittmar (2000) ${ }^{[2]}$ found that managers are willing to exchange investment and employment opportunities for share repurchase. Non-family firms are more likely to exchange investment and $R \& D$ expenditure for share repurchase, while non-family firm are less inclined to repurchase shares (Shane,2019) ${ }^{[6]}$. Although the research by Almeida (2016) ${ }^{[1]}$ and Shane (2019) ${ }^{[5]}$ mentioned that share repurchase has a restraining effect on $R \& D$ expenditure, there are great differences among different industries, and the relationship between share repurchase and $R \& D$ expenditure may be different due to different emphasis on R\&D investment. This paper studies the relationship between share repurchase and R\&D expenditure in high-tech industry.

This paper holds that share repurchase affects the $R \& D$ expenditure of enterprises in two ways: first, share repurchase reduces the total number of shares outstanding which is equivalent to increasing the shareholding of managers in disguise. The association between executives and the company is strengthened, so that senior executives pay more attention to the long-term profitability of the enterprise and promote the investment in R\&D. Second, repurchase signals to investors good news of the company, and conveyed the company's future development prospects to investors. For high-tech 
enterprises, $R \& D$ expenditure is an important factor for the future sustainable development of enterprises. For the long-term development of enterprises, they will inevitably invest a lot of R\&D funds. This paper proposes a hypothesis: for high-tech firms, repurchase will promote the investment of R\&D.

\section{Sample selection and research methodology}

\subsection{Sample and data}

In this paper, we take the high-tech listed companies in Shanghai and Shenzhen stock markets in 2008-2018 as samples, and processes the samples as follows. (1) Eliminate samples of listed companies that are ST and * ST; (2) Eliminate the samples of missing data; (3) Winsorize the continuous variables in this paper at $1 \%$ and $99 \%$ sub-bits. The data in this paper are mainly from the CSMAR database and the RESSET database.

\subsection{Measurements methods}

Dependent variable. Share repurchase, the dummy variable, when the company completed share repurchase, this indicator is marked as " 1 "; otherwise, this indicator is marked as " 0 ".

Independent variable. $\mathrm{R} \& \mathrm{D}$, the dummy variable, when the company completed $R \& D$ expenditure in the year of repurchase, this indicator is marked as " 1 "; otherwise, this indicator is marked as " 0 ".

Control variables. The paper chooses some variables as control variables based on the previous literature (Ikenberry, 1995)[4]. The control variables include the return on assets (ROA) measured by net profit after tax / total assets, corporate cash flow level (Cash) measured by $\log$ of corporate cash flow, sales growth rate (Growth) measured by corporate net profit growth rate, company value (Tobin'q), firm size (Size) measured by log of total assets, financial leverage (Lev)measured by asset-liability ratio, ownership concentration ( Top1), measured by shareholding of the largest shareholder, the equity balance (EB), measured by shareholding ratio of the first largest shareholder / Shareholding ratio of the second to ten largest shareholders and the age of the enterprise (Age) measured by Year of establishment. In addition, we control annual fixed effect.

\subsection{Empirical model}

Based on the idea of Dittmar (2000), this paper establishes model 1 to test the hypothesis:

$R e p=\alpha_{0}+\alpha_{1} R \& D+\alpha_{2}$ Control $+\sum$ Year $+\varepsilon(1)$

This paper focuses on the significance and direction of $\alpha_{1}$. If $\alpha_{1}$ is significantly positive, then the hypothesis in this paper is proved to be valid.

\section{Empirical results}

\subsection{Descriptive Statistics}

Table 1 shows the descriptive statistics and correlation analysis results of the above variables. In the high-tech industry, the mean (0.710) and median (1.000) of R\&D expenditure are higher than those of share repurchase $(0.181)$ and (0.000), indicating that the high-tech industry pays more attention to enterprise $R \& D$ expenditure. From the correlation analysis, it is known that the share repurchase and $R \& D$ are statistically significant, and they are also significantly significant with other control variables. The maximum VIF value is 2.58 , which is far less than 10, indicating that there is no serious multicollinearity between variables.

Table 1. Descriptive statistics and correlation analysis.

\begin{tabular}{|c|c|c|c|c|c|c|c|c|c|c|c|}
\hline Var & Rep & R\&D & ROA & Lncash & Growth & Tobinq & Size & Lev & Top1 & EB & Age \\
\hline Obs & 7163 & 7163 & 7163 & 7163 & 7163 & 7163 & 7163 & 7163 & 7163 & 7163 & 7163 \\
\hline Mean & 0.181 & 0.710 & 0.069 & 17.934 & 0.267 & 2.833 & 21.513 & 0.386 & 0.345 & 1.088 & 21.36 \\
\hline Std & 0.385 & 0.454 & 0.074 & 1.776 & 2.726 & 2.391 & 1.226 & 0.257 & 0.156 & 0.835 & 4.794 \\
\hline Min & 0.000 & 0.000 & -0.212 & 5.050 & -12.04 & 0.136 & 18.708 & 0.008 & 0.090 & 0.056 & 9.000 \\
\hline Med & 0.000 & 1.000 & 0.060 & 17.907 & 0.167 & 2.203 & 21.467 & 0.375 & 0.319 & 0.881 & 21.00 \\
\hline Max & 1.000 & 1.000 & 0.318 & 21.390 & 15.811 & 13.561 & 24.918 & 8.009 & 0.810 & 4.185 & 67.00 \\
\hline Rep & 1.000 & $* * *$ & $* * *$ & $* * *$ & $* * *$ & & $* * *$ & & $* * *$ & $* * *$ & \\
\hline $\mathrm{R} \& \mathrm{D}$ & 0.271 & 1.000 & $* * *$ & $* * *$ & $* *$ & $* * *$ & $* * *$ & $* * *$ & $* * *$ & $* * *$ & $* * *$ \\
\hline ROA & -0.160 & -0.212 & 1.000 & $* * *$ & $* * *$ & & $* * *$ & $* * *$ & $* * *$ & $* * *$ & $* * *$ \\
\hline Lncash & 0.264 & 0.220 & -0.250 & 1.000 & $* *$ & $* * *$ & $* * *$ & $* * *$ & $* * *$ & $* * *$ & $* * *$ \\
\hline Growth & -0.056 & -0.023 & 0.207 & 0.037 & 1.000 & $* * *$ & $* *$ & $*$ & & $*$ & $* * *$ \\
\hline
\end{tabular}




\begin{tabular}{|c|c|c|c|c|c|c|c|c|c|c|c|}
\hline Tobinq & -0.001 & 0.272 & 0.014 & -0.069 & 0.051 & 1.000 & $* * *$ & $* * *$ & $* * *$ & $* * *$ & $* * *$ \\
\hline Size & 0.251 & 0.285 & -0.343 & 0.736 & 0.030 & -0.073 & 1.000 & $* * *$ & $* * *$ & $* * *$ & $* * *$ \\
\hline Lev & -0.018 & -0.241 & -0.188 & 0.190 & -0.021 & -0.129 & 0.199 & 1.000 & $* * *$ & $* * *$ & $* * *$ \\
\hline Top1 & -0.143 & -0.255 & 0.203 & -0.106 & 0.015 & -0.179 & -0.167 & 0.039 & 1.000 & $* * *$ & $* * *$ \\
\hline EB & 0.046 & 0.087 & 0.110 & -0.080 & 0.021 & 0.055 & -0.080 & -0.129 & -0.672 & 1.000 & $* * *$ \\
\hline Age & -0.013 & -0.068 & -0.136 & 0.119 & 0.035 & 0.036 & 0.159 & 0.119 & -0.120 & -0.050 & 1.000 \\
\hline VIF & & 2.58 & 2.51 & 2.27 & 2.22 & 1.44 & 1.4 & 1.18 & 1.16 & 1.09 & 1.05 \\
\hline
\end{tabular}

Column (1) in table 2 shows the regression results of model (1). From the results in column (1), the coefficient of independent variable $\mathrm{R} \& \mathrm{D}$ is 4.182 , which is significantly positive at the level of $1 \%$. Different from the conclusion of Shane, it shows that there is a positive correlation between share repurchase and R\&D expenditure. It indicates that in the high-tech industry, the company does not exchange share repurchase for $R \& D$ expenditure. It can also be seen that share repurchase behavior is positively correlated with return on assets, free cash flow level, growth and financial leverage ratio, and they are statistically significant.

Further, this paper divides firms into state-owned enterprises and non-state-owned enterprises according to the nature of property rights of firms, and discusses the impact of share repurchase on R\&D expenditure under different natures of property rights. The performance evaluation of managers of non-state-owned enterprises is linked to the operating performance of the enterprise, and they have more incentives to choose to repurchase shares for the short-term gains. Rather than considering the long-term development of the company. State-owned enterprises bear more social responsibilities, such as guaranteeing employment, etc. The performance appraisal of managers considers the long-term development of enterprises more, and it is unlikely to give up the investment in R\&D for the sake of short-term income. Therefore, compared with non-state-owned enterprises, share repurchase plays a more positive role in promoting R\&D expenditure in state-owned enterprises. This paper introduces model (2) to test the above logic.
SOE refers to the property right of an enterprise. When the company is a state-owned enterprise, this indicator is marked as " 1 "; otherwise, this indicator is marked as " 0 ". To test the above model, we mainly observe the significance and direction of $\beta_{3}$. If $\beta_{3}$ is significantly positive, the above logic is proved to be correct.

The test results are shown in Column (2) in table 2. The coefficient of $\mathrm{R} \& \mathrm{D} * \mathrm{SOE}$ is 0.612 , which is significant at the level of $1 \%$, and $\beta_{3}$ is significantly positive. This shows that the positive relationship between the share repurchase and $R \& D$ expenditure of state-owned enterprises is more significant than that of non-state-owned enterprises. The above logic is correct.

Finally, this paper tests the robustness of model (1) by replacing the measures of enterprise $R \& D$ expenditure. This article uses the company's R\&D expenditure (RDM) (natural log of the total amount of R\&D expenditure) and the ratio of R\&D expenditure to operating income (RDS) to measure the company's R\&D expenditure, and rerun the model (1). The regression results are shown in columns (3) and (4) of Table 2.

It can be seen from columns (3) and (4) in Table 2 that the coefficient of RDM is 1.359 , which is significant at the level of $1 \%$; the coefficient of RDS is 1.030 , which is significant at the level of $5 \%$. The result is similar to column (1), indicating that share repurchase is positively related to $R \& D$ expenditure, and model (1) results are robust.

Table 2. regression results.

\begin{tabular}{|c|c|c|c|c|c|c|c|c|}
\hline \multirow[t]{2}{*}{ Var } & \multicolumn{2}{|c|}{ (1) } & \multicolumn{2}{|c|}{ (2) } & \multicolumn{2}{|c|}{ (3) } & \multicolumn{2}{|c|}{ (4) } \\
\hline & $\begin{array}{c}\text { Coefficie } \\
\text { nt }\end{array}$ & T-value & $\begin{array}{c}\text { Coefficie } \\
\text { nt }\end{array}$ & $\begin{array}{c}\text { T-valu } \\
\text { e }\end{array}$ & $\begin{array}{c}\text { Coefficie } \\
\text { nt }\end{array}$ & T-value & $\begin{array}{c}\text { Coefficie } \\
\text { nt }\end{array}$ & $\begin{array}{c}\text { T-valu } \\
\text { e }\end{array}$ \\
\hline R\&D & $4.182 * * *$ & 5.420 & $3.594 * * *$ & 5.680 & & & & \\
\hline RDM & & & & & $1.359 * * *$ & 4.190 & & \\
\hline RDS & & & & & & & $1.030 * *$ & 2.530 \\
\hline SOE & & & $0.535^{*}$ & -1.670 & & & & \\
\hline $\begin{array}{c}\mathrm{R} \& \mathrm{D}^{*} \mathrm{~S} \\
\mathrm{OE}\end{array}$ & & & $0.612 * * *$ & -4.070 & & & & \\
\hline ROA & $0.083 * *$ & -2.470 & $0.228 * *$ & -2.320 & $0.075 * *$ & -2.350 & $0.142 *$ & -1.830 \\
\hline
\end{tabular}




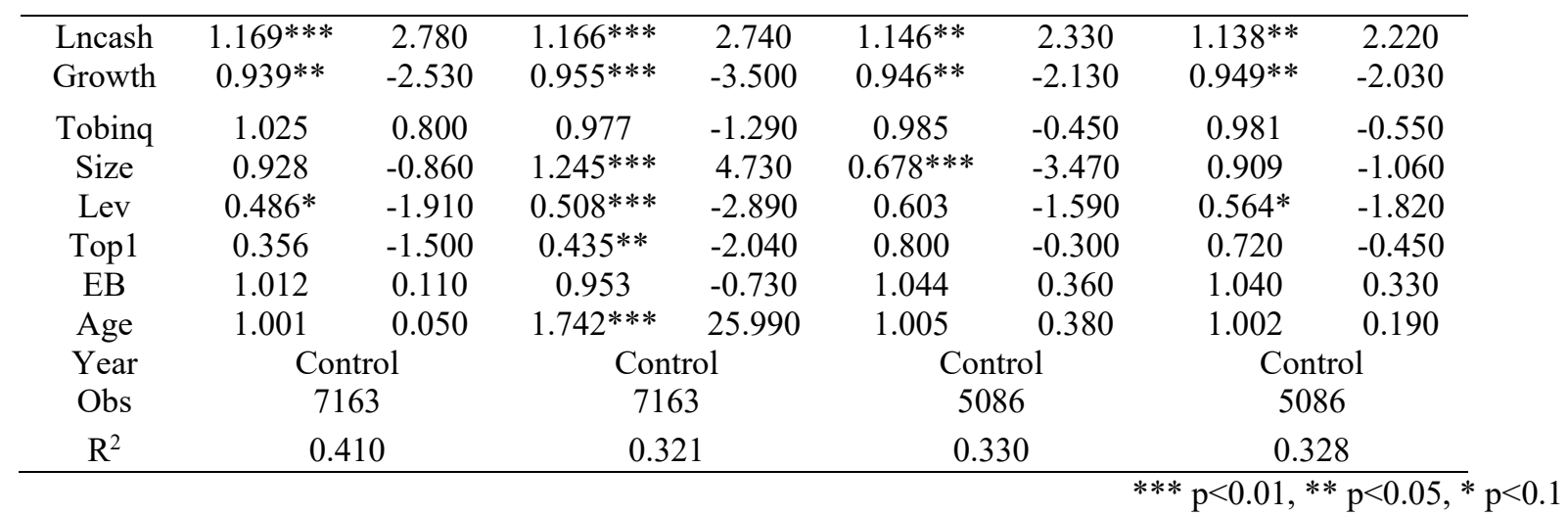

\section{Summary and conclusions}

Based on data from listed companies that implemented repurchases in China's Shanghai and Shenzhen stock markets from 2008 to 2018 , this paper uses a logit regression model to test the impact of share repurchases on $R \& D$ expenditure in the high-tech industry. Inconsistent with the research conclusions of (Almeida, 2016; Shane, 2019) ${ }^{[1,5]}$, this paper finds that in the high-tech industry, enterprises will not exchange $R \& D$ expenditure with share repurchases. On the contrary, repurchase will promote the investment of $R \& D$ expenditure in high-tech industry.

The main contributions of this paper are as follows: on the one hand, the research on the relationship between share repurchases and $R \& D$ expenditure enriches the literature on the economic consequences of share repurchases; on the other hand, it helps investors to identify the share repurchase behavior of listed companies and safeguard the interests of investors.

\section{References}

1. Almeida H.; Fos V.; Kronlund M, The Real Effects of Share Repurchases J. Financ. Econ. 2016, 119(1):168-185.

2. Dittmar, Amy K, Why Do Firms Repurchase Stock? J. Bus. 2000,73(3):331-355.

3. Dittmar,Amy, Laura, Can managers time the market? Evidence using repurchase price data J. Financ. Econ. 2015,115(2):261-282.

4. Ikenberry D.; Lakonishok J.; Vermaelen T, Market underreaction to open market share repurchases $\mathrm{J}$. Financ. Econ. 1995,39, 181-208.

5. Shane Dalsem A V, Does founding family involvement affect share repurchase activity? Evidence from US firms from 2006 through 2015 Manag. Financ. 2019,45(8):1146-1163.

6. Tong J, Bremer M, Stock repurchases in Japan: A solution to excessive corporate saving? J. Japanese Int. Econ. 2016, 41:41-56. 